\title{
Age Discrimination in the Republic of Macedonia and the Approach of the Constitutional Court
}

\author{
Ass. Prof. Bekim Kadriu, PhD \\ State University of Tetova, Republic of Macedonia \\ bekimkadriu23@yahoo.com
}

Ass. Prof. Bujar Ahmedi, PhD

State University of Tetova, Republic of Macedonia

bujarahmedi@unite.edu.mk

Doi:10.5901/ajis.2015.v4n2p241

\section{Abstract}

The Constitutional court of the Republic of Macedonia has a jurisdiction to deal with cases of alleged inter alia age discrimination. This jurisdiction derives directly from the Constitution, which makes the Constitutional court the highest court deciding on cases of human rights violations, including discrimination. In it's jurisdiction, the Constitutional court has dealt with issues of age distinctions, such as the mandatory retirement or the use of age as a criterion in access to different benefits. The paper focuses on the approach of the Constitutional court of the Republic of Macedonia towards the concept of age discrimination. Namely, in its jurisdiction when dealing with such cases the Constitutional Court doesn't apply the test of proportionality. Wrongly, the Court accepts age as being objective criterion in employment or education. In this way, the Constitutional Court even contradicts with Macedonia's international obligations and the case-law of the main international jurisdictions, such as the Court of Justice of the European Union. The paper points out the national legal framework, as well as international standards, on protection from age discrimination.

Keywords: human rights, constitutional court, discrimination, ageism;

\section{Introduction}

Age based discrimination appears in different areas, but it prevails in the work place, education, access to goods and services, health services etc. It appears in various forms and it has a different effect on different categories of people (according to age - older or younger).

Age discrimination, generally speaking, is a concept that is hard to accept as it is (as discrimination) by individuals, as well as by institutions. This fact can be confirmed by the small number of reported and solved cases of age discrimination, which, on the other hand, complicates the debate of whether there is or there is not existing this type of discrimination.

In the fulfillment of its own mandate, the Constitutional Court of the Republic of Macedonia considered several cases in relation to the age discrimination. The approach of the Constitutional Court is very specific, i.e. it is contrary to all the relevant international jurisdictions, which made it the main theme of this paper.

\section{National Legal Framework for Protection Against Age Discrimination}

Republic of Macedonia has adopted legislation for protection from discrimination. This legislation protects age as a separate ground for discrimination. Apart from the Constitution, The Law on Prevention and Protection from Discrimination [hereinafter "LPPD"], ${ }^{1}$ applied since 2011 , is also very important.

${ }^{1}$ The Law on Prevention and Protection from Discrimination [hereinafter "LPPD"], Official Gazette of the Republic of Macedonia, No $50 / 2010$. 


\subsection{Article 9 of the Constitution and Age discrimination}

In the Republic of Macedonia, the principle of equality arises from the Constitution of the RM. Although in the provision of the Constitution which guarantees equality, age is not mentioned as a separate ground of discrimination, ${ }^{2}$ one cannot conclude that Macedonia does not have a constitutional ground for development of legislation for prevention and protection from age discrimination. The omission of age as a separate ground for discrimination in the constitutional antidiscrimination clause was not an obstacle to the further development of legislation regarding the protection from discrimination. This can be clearly seen by the explicit stipulation of age as a discriminatory ground in several laws. Thus, age is mentioned in the Law on Labor, ${ }^{3}$ Law on Volunteerism ${ }^{4}$ and the Law on Prevention and Protection from Discrimination. ${ }^{5}$ The recommendation remains for the provision of Article 9 of the Constitution to be amended, and other grounds of discrimination to be enumerated, such as age, disability and sexual orientation.

\subsection{The general Law on Prevention and Protection from Discrimination and age discrimination}

The Law on Prevention and Protection from Discrimination (LPPD) is being applied since the beginning of 2011, and age is specifically mentioned in its Article 3 as a separate ground of discrimination. Beside the inclusion of age as a separate ground of discrimination, what is important to mention about LPPD, is definitely its wide material scope. The provisions of LPPD explicitly establish that discrimination is prohibited in the following areas: work and employment relations; education, science and sport; social security, including the area of social protection; judiciary and administration; housing; public information and media; access to goods and services of public character; membership and activities in unions, political parties, associations of citizens and foundations or other organizations based on membership; culture, and other areas provided by law. ${ }^{6}$

Taking into consideration the wide material scope of applying the LPPD, it can be said that age discrimination is prohibited in all the areas where more developed national legislations prohibit it. Besides, it includes the areas pointed out by the EU Directive establishing a general framework for equal treatment in employment and occupation. ${ }^{7}$

In the Authors' opinion, this constitutional provision should be changed in the near future, because it is contrary to the provisions of those laws that include wider lists of grounds of discrimination, such as the Labor Law, Law on Social Protection ${ }^{8}$, Law on Protection of Patients' Rights, ${ }^{9}$ Law on Volunteerism ${ }^{10}$ and the Law on Prevention and Protection of Discrimination.

What is problematic about LPPD as a general anti-discrimination law is the fact that the exemptions from discrimination are not precisely defined. In particular, given that it is a general law (many grounds of discrimination and wide material application), it is impossible for all the types of exemptions from discrimination to be explicitly enlisted. It is recommended to include a general possibility for justification of the distinctions made through the grounds enumerated in Article 3 , including the distinctions made based on the age of the individual.

Also, it is very important to harmonize other separate material laws which contain anti-discrimination clauses with LPPD as a general law, because there has been confusion so far. Specifically, special laws related to areas covered by LPPD, although adopted later than LPPD, do not include age as a separate ground of discrimination. Such laws are as follow: Law on social protection ${ }^{11}$ and Law on public health. ${ }^{12}$ Also, although not directly related to age discrimination, but

\footnotetext{
${ }^{2}$ The Constitution of the Republic of Macedonia, Official Gazette of the Republic of Macedonia, No. 52/1991. Its Article 9 states that : "Citizens of the Republic of Macedonia are equal in their freedoms and rights, regardless of sex, race, color of skin, national and social origin, political and religious beliefs, property and social status". This provision of the Constitution has been criticized in terms of modern models of constitutional anti-discrimination clauses, because it does not contain some significant and current grounds of discrimination, such as sexual orientation, disability and age, and on the other hand, the list of prohibited grounds is closed.

3 Law on Labor Relations, Official Gazette of the Republic of Macedonia no. 62/2005, Articles 6-9.

${ }^{4}$ Law on Volunteerism, Official Gazette of the Republic of Macedonia no. 85/2007, Article 9.

${ }^{5}$ LPPD, Article 3.

${ }^{6}$ LPPD, Article 4.

7 Council Directive 2000/78/EC of 27 November 2000 establishing a general framework for equal treatment in employment and occupation, O.J. L 303, 02/12/2000 P. 0016 - 0022.

${ }^{8}$ Law on social protection, Official gazette of the Republic of Macedonia, no. 148/2013.

${ }^{9}$ Law on Protection of Patients' Rights, Official gazette of the Republic of Macedonia, no.82/2008.

10 Law on Volunteerism, Official Gazette of the Republic of Macedonia no. 85/2007.

11 Law on social protection, Official gazette of the Republic of Macedonia, no. 148/2013, Article 20. 
still having an effect over them, it is necessary for the definitions of discrimination to comply, as well as the exceptions of discrimination.

The Law on Prevention and Protection from Discrimination establishes a separate body for protection from discrimination, which is the Commission for Protection from Discrimination, and it predicts a special court proceeding for protection from discrimination which is novelty in the national legal system ${ }^{13}$.

\subsection{Special laws and age discrimination}

Besides in the LPPD, as previously mentioned, the age of the individual as a ground of discrimination is included in other laws related to special areas of public life. Thus, the Law on Labor Relations ${ }^{14}$ and the Law on Volunteerism ${ }^{15}$ stipulate age as a separate ground of discrimination. But not all special laws in their non-discrimination clauses include age as a specific discriminatory ground. For this reason, it is necessary the other special laws regarding education, social protection, social and pension insurance, housing, health services, bank and insurance services and other services of public character, to include age as a specific discriminatory ground.

Also, it remains as a need to harmonize the anti-discrimination clauses of the special laws with the general LPPD. Not only to the protected grounds, but these special laws have to follow the line and reasoning of LPPD in relation to the definitions of the different forms of discrimination (direct discrimination, indirect discrimination, harassment, victimization and instruction to discriminate), as well as to exceptions from discrimination. In other words, where the special law does not contain specific definitions of discrimination, or exceptions, the provisions of LPPD should be guiding the behavior of institutions that are required to apply specific laws. This approach should be taken since LPPD is general law, and covers all enlisted areas.

\section{International Obligations of R. of Macedonia Towards Protection from Age Discrimination}

In terms of international law, Macedonia has undertaken obligation, above all, to adopt appropriate legislation for prevention and protection from age discrimination. But despite the adoption of legislation, the responsibility for its application and successful and efficient implementation is also very important. By adopting the LPPD, the Republic of Macedonia fulfills its obligation about adoption of appropriate legislation. We claim this taking into consideration that LPPD is a general law that covers all possible discriminatory grounds, and has a wide material scope, covering all areas required by the international agreements ratified by the Republic of Macedonia. What remains is the application of the LPPD and the other specific laws, which are also very important for our commitments made under international law.

These two crucial obligations arise from the following, but not the only, ratified treaties: International Covenant on Civil and Political Rights, ${ }^{16}$ the International Covenant on Economic, Social and Cultural Rights, ${ }^{17}$ the Convention on the Rights of the Child, ${ }^{18}$ European Convention on Human Rights ${ }^{19}$ and its Protocol $12 .{ }^{20}$

After the Treaty of Amsterdam, ${ }^{21}$ through its Article 13, the European Union institutions gain competence to undertake measures for the fight against discrimination on grounds of inter alia age. For some grounds of discrimination,

\footnotetext{
12 Law on public health, Official gazette of the Republic of Macedonia, no 22/2010, Article 16, paragraph 5.

${ }_{13}^{13}$ LPPD, Articles 16-33 regulate the issues related to the Commission, while Articles 34-41 regulate the court proceeding for protection from discrimination.

14 Law on labour relations, supra, foot note 3. Article 6.

${ }^{15}$ Law on volunteerism, supra foot note 4, Article 9.

16 UN Genaral Assembly, International Covenant on Civil and Political rights, 16 December 1966, United Nations, Treaty Series Vol. 999, page 171 available at http://www.refworld.org/docid/3ae6b3aa0.html [last accessed 29 November 2014]

17 UN General Assembly, International Covenant on Economic, Social and Cultural Rights, 16 December 1966, United Nations, Treaty Series Vol. 999, page 3, available at ttp://www.refworld.org/docid/3ae6b36c0.html [accessed 29 November 2014].

18 UN General Assembly, Convention on the Rights of the Child, 20 November 1989, United Nations, Treaty Series, vol. 1577, p. 3, available at: http://www.refworld.org/docid/3ae6b38f0.html [accessed 29 November 2014]

${ }^{19}$ Council of Europe, European Convention for the Protection of Human Rights and Fundamental Freedoms, as amended by Protocols Nos. 11 and 14, 4 November 1950, ETS 5, available at: http://www.refworld.org/docid/3ae6b3b04.html [accessed 29 November 2014].

20 Council of Europe, European Convention for the Protection of Human Rights and Fundamental Freedoms, as amended by Protocols Nos. 11 and 14, 4 November 1950, ETS 5, available at: http://www.refworld.org/docid/3ae6b3b04.html [accessed 29 November 2014]. ${ }^{21}$ European Union, Treaty on European Union (Consolidated Version), Treaty of Amsterdam, 2 October 1997, available at: http://www. refworld.org/docid/3dec906d4.html [accessed 29 November 2014]
} 
such as gender and racial and ethnic origin, special directives have been adopted. On the other hand, for grounds such as religion and belief, disability, sexual orientation and age, one single directive has been adopted, and that is the Council Directive 2000/78 / EC for equal treatment in employment and occupation. ${ }^{22}$

It is important to notice that this is the only Directive that offers protection from age discrimination within the EU, and is applicable only in the area of employment. The EU institutions haven't found the strength to adopt a Directive that will protect age discrimination (and discrimination based on religion or belief, sexual orientation and disability) out of the area of employment. Such initiative exists through the EU Draft-Directive for implementation of the principle of equal treatment of people regardless of their religion or beliefs, disability, age ot sexual orientation. ${ }^{23}$ This document (proposal for a directive) rewrites the definitions of direct and indirect discrimination ${ }^{24}$ from other directives in force, same definitions for harassment is accepted, ${ }^{25}$ as well as victimization ${ }^{26}$ and the principle of shifting of the burden of proof. ${ }^{27}$

The crucial difference of the proposal for Directive is its material scope. Its basic goal is to create EU legislation that will offer protection for other grounds of discrimination (age, sexual orientation, disability and religion an beliefs), in the areas where directives of race and gender are applied accordingly (including education, health services, social protection, housing, approach to goods and services). This would ensure equal legal protection for all grounds. However, this Proposal for Directive is not yet part of the EU legislation.

Despite the proposal for directive, another significant document is the EU Charter on Fundamental Rights 28 (hereinafter "The Charter"), which represents a part of the primary sources of EU law, given that it was part of the Lisbon Treaty. ${ }^{29}$ Two provisions of the Charter limit its application. The first one is the one that states that "provisions of this Charter are related to the institutions and bodies of the Union ... and the member-states, only in cases when they implement the EU law". ${ }^{30}$ Thus, individuals have no right to claim violation of their rights, including discrimination, against other legal entities, but only against the EU institutions as well as against domestic authorities, and only if they acted upon the EU law. On the other and, the Charter contains a provision which specifically claims that the Charter has no influence in a direction of expansion or addition of the Union's competences. ${ }^{31}$ This means that the powers of the Union remain the same, within existing contracts as primary legislation. Charter does not create new areas that exceed the competence of the Union.

These two provisions limit the application of the Charter, and therefore some authors consider that the Charter cannot create new areas of application of EU law. ${ }^{32}$ For these reasons, the EU directives are legal documents that create the framework for protection of discrimination and most of them do not include age discrimination.

\section{Age Discrimination in R. of Macedonia}

\subsection{Use of age distinctions}

In the Republic of Macedonia, age-based distinctions are mostly used in labor relations. In this area age is used as criterion for recruitment but also as a criterion for ending a job relation, either through dismissal or through retirement. When it comes to the first case, in the Republic of Macedonia, it is very common age to be used as a criterion in the

22 Council Directive 2000/78/EC of 27 November 2000 establishing a general framework for equal treatment in employment and occupation, O.J. L 303, 02/12/2000 P. 0016 - 0022.

${ }^{23}$ Proposal for a Council Directive on implementing the principle of equal treatment between persons irrespective of religion or belief, disability, age or sexual orientation, SEC(2008) 2180), 2 July 2008, accessible at http://eur-lex.europa.eu/LexUriServ/LexUriServ.do? uri=CELEX:52008PC0426:EN:NOT [las accessed 11 November 2014]

24 Ibid., Article 2.2.

25 Ibid., Article 2.3.

26 Ibid., Article 9.

${ }^{27}$ Ibid., Article 8.

${ }^{28}$ Charter of Fundamental Rights of the European Union, 26 October 2012, 2012/C 326/02) available at http://eur-lex.europa.eu/LexUri Serv/LexUriServ.do?uri=0J:C:2010:083:0389:0403:en:PDF [accessed 7 November 2014].

${ }^{29}$ European Union, Treaty of Lisbon Amending the Treaty on European Union and the Treaty Establishing the European Community, 13 December 2007, 2007/C 306/01, available at: http://www.refworld.org/docid/476258d32.html [accessed 29 November 2014]

30 lbid., Article 51.1.

$31 \mathrm{lbid}$., Article 51.2.

${ }^{32}$ Rebecca Zahn, The EU Lisbon Treaty: What Implications for anti racism, Brussels, 2009, page 18. 
announcement for job vacancies, ${ }^{33}$ although age can rarely be a substantial condition for performing tasks. These practices are most often found as discriminatory because age can be important only for a small number of work posts. ${ }^{34}$ Age as a criterion for employment is used especially by private employers who have no sensibility that they must not set such discriminatory criteria.

Age is also used as a criterion for termination of employment. A classic example for this case, in the Republic of Macedonia, are professional soldiers, which according to the Law on Military Service of the Republic of Macedonia, cannot sign an employment contract if they are at the age of $38 .{ }^{35}$ According to the provisions of this law, professional soldiers can sign employment contracts for a definite term of 3 years, and this contract in no way can continue after the age of 38 years. ${ }^{36}$

In addition, in the Republic of Macedonia there is a possibility when an employee terminates employment with retirement just because he/she reached a certain age. ${ }^{37}$ Compulsory retirement is stipulated in the Law on Labor Relations ${ }^{38}$ and in several other laws that apply to the public sector, such as the Law on Courts, ${ }^{39}$ the Law on Public Prosecution, ${ }^{40}$ Law on Civil Servants, ${ }^{41}$ Law on Notary ${ }^{42}$ and Law on Higher Education. ${ }^{43}$ These laws stipulate the termination of employment when a person reaches a certain age, without taking into consideration the will of the employee and his/her ability to work. This type of termination of employment according to its definition is less favorable treatment on grounds of age of the employee. Workers affected by these rules can easily prove the existence of less favorable treatment, which will shift the burden of proof on the side of the defendant (state authorities), who will have to prove that termination of employment due to age is justified. They should prove that this is a necessary measure for reaching some legitimate goal, like for example, easier approach to work for younger people.

At the EU level, the Court of Justice of the European Union has taken the approach that mandatory retirement must not be accepted a priori as justified. In order to have mandatory retirement the requirement of necessity and proportionality provided in Article 6 of the Directive 2000/78/EC must be met. ${ }^{44}$ This approach allows mandatory retirement to be put under judicial control and not to affect disproportionably workers who are capable and willing to work. Unfortunately, our Constitutional Court does not accept this reasoning, as discussed below.

In Macedonia, distinctions based on age are used in the field of education, as members of certain age groups are excluded of the possibility of using certain benefits. Thus, according to Regulation methods and procedures for funding, creation and development of scientific research staff, 45 for awarding scholarship for postgraduate studies in the country or second cycle studies abroad, the candidate must not be older than 27 years, for the first, and must not be older than 28 years, for the second year. ${ }^{46}$ And for giving the one-time financial assistance for the preparation of master or doctoral thesis, the candidate is required, on the day of filing, not to be older than 30 (master thesis) or 38 years (doctoral

${ }_{33}$ See advertisement for recruitment of www.vrabotuvanje.mk day September 2, 2013, which reads: "The company "INTER INZHENERING" for the "MODA DI BANJO" salon recruits: shop assistant with secondary education (advantage is given to the technical area), with knowledge in computers, diving license, not older than 30 years, with or without working experience. Interested candidates should submit their CVs to the following address: Gradski Zid blok 11/3 or Fax 02-3213-454 INTER INZHENERING SKOPJE". Avilable at www.vrabotuvanje.mk [accessed 11 August 2014].

${ }^{34}$ As examples, in the announcement for job vacancies for models for clothes for children, it is possible the age of applicants to be relevant. Also contests that require an actor to play the role of a certain younger or older person where age can also be relevant.

${ }^{35}$ Law on Military Service of the Republic of Macedonia, Official Gazette of the Republic of Macedonia, no. 36/2010, Article 40.

$36 \mathrm{Ibid}$, Article 40, paragraphs 2 and 3.

${ }^{37}$ Law on Changes and Amendment to the Law on Pension and Disability Insurance, Official Gazette of the Republic of Macedonia, no. 24/2000). Accordin to this law, the retirement conditions are the employees' age (64 for men and 62 for women), as well as at least 15 years of service.

${ }^{38}$ Law on Labor Relations, supra foot note 3, Article 104.

${ }^{39}$ Law on the courts, Official gazette of the Republic of Macedonia, no, 58/2006, Article 73.

40 Law on Public Prosecution, Official gazette of the Republic of Macedonia, no 150/2007, Article 66

${ }^{41}$ Law on Civil Servants, Official gazette of the Republic of Macedonia, no 108/2005, Article 108.

42 Law on Notary, Official gazette of the Republic of Macedonia, no 55/2007, Article 14.

${ }^{43}$ Law on Higher Education, Official gazette of the Republic of Macedonia, no 35/2008, Article 147.

${ }^{44}$ European Court of Justice, Case C-411/05, Felix Palacios de la Villa v. Cortefiel Servicios SA [2007], ECR, I-8531.

${ }^{45}$ Regulation methods and procedures for funding, creation and development of scientific research staff, Official Gazette of the Republic of Macedonia no. 18/2012.

${ }^{46} \mathrm{Ibid}$., Article 3, paragraph 1, indent 4 and Article 5, paragraph 1, indent 4. 
thesis). ${ }^{47}$

In other areas, age distinctions in Macedonia are used in the social security, access to financial services, particularly banking and insurance services, as well as other areas. Just as an example, the Law on Social Protection, for many benefits, uses age as a criterion. ${ }^{48}$ Also, many banks in the country use age as a criterion for different financial services that they offer..$^{49}$ In this way, it is clear that age is often used as a criterion in different areas, but what lacks is the judicial control. For this we discuss below.

\subsection{Perception of age discrimination}

Regarding the perception of age-based discrimination, according to Barometer survey for Equal Opportunities, age is perceived as a fifth ground of discrimination, after political and ethnic affiliation, sexual orientation and disability. According to $39,8 \%$ of the participants in the survey, age-based discrimination is very common in the country. ${ }^{50}$

It is necessary to mention that, according to this survey, the percentage of people who believe that there is discrimination based on age in the country, decreased compared to 2009. According to the research from 2009, age appears as the third most common discriminatory basis, while $48.5 \%$ of the participants in the survey think that agebased discrimination is very common in the country. ${ }^{51}$

\subsection{Reported cases on alleged age discrimination}

In terms of reported cases of age discrimination, according to institutions, for the last 5 years and out of over 200 cases of alleged discrimination, no case of age discrimination was filed in the Ombudsman. ${ }^{52}$

Before the Commission for Protection from Discrimination, and within three years of its existence, the number of cases of age discrimination is low. Thus, in 2011, out of total 63 cases, only 4 or $6,35 \%$ of the cases were based on age discrimination. In 2012, out of total of 76 submitted complaints of alleged discrimination, only 3 (3.95\%) are based on age. In 2013, out of total of 84 complaints, $4(3.9 \%)$ are related to age discrimination. ${ }^{53}$ It can be noticed that the overall number of complaints in front of the Commission for Protection from Discrimination is increasing, while the number of complaints of alleged age discrimination remains the same.

Before regular courts there is no data of initiated proceedings related to age discrimination, while the Constitutional Court has decided on the matter, to which we refer below.

\section{The Approach of the Constitutional Court of the R. of Macedonia}

As mentioned previously, the Constitutional Court in the exercise of its own jurisdiction, ${ }^{54}$ has dealt at least two cases of age discrimination. In the first case of 2003, the Constitutional Court had the opportunity to decide on the mandatory retirement of members of the Judicial Council of the Republic of Macedonia. In this case, the Constitutional Court does not analyze whether the principle of necessity for the existence of such a rule is respected, as it requires the European Court of Justice. ${ }^{55}$ On the contrary, the Constitutional Court finds that the age of the individual is "legitimate criterion for regulation of human labor activity "and that "ageing of people is natural and objective fact which binds the termination of

47 Ibid., Article 15, paragraph 1, indent 2.

48 See eg, Law on Social Protection, supra foot note 8, Article 58.

${ }^{49}$ See eg. Criteria for loans used by Stopanska Banka Skopje, available at www.stb.com.mk/consumer-loan.nspx [accessed 29 November 2014].

50 Jasmina Mihailoska, Misha Popoviq, BAROMETER FOR EQUAL OPPORTUNITIES, Skopje, 2013, page 11.

51 Violeta Petroska Beshka, Mirjana Najcevska, BAROMETER FOR EQUAL OPPORTUNITIES, Skopje, 2009, page 14.

${ }^{52}$ Ombudsman of the Republic of Macedonia, Annual Report on the level of fulfillment, respect, advancement and protection of human rights and freedoms for 2009, 2010, 2011, 2012, 2013 and 2014, available at www.ombudsman.mk [accessed 1 November 2014].

${ }^{53}$ Commission for Protection from Discrimination, Regular Annual report of the Commission for protection against discrimination, for 2011, 2012 and 2013, available at www.kzd.mk [accessed 21.10.2014]

${ }^{54}$ Constitution of the Republic of Macedonia, supra foot note 2, Article 110, paragraph 1. In this provision, it is prescribed that the Constitutional Court can accept individual complaints by individuals who consider themselves to be victim of discrimination.

55 See supra foot note 44 and accompanying text. 
the working period". ${ }^{56}$

With this attitude, the Constitutional Court goes in the opposite direction of all modern trends of development of legal science. In comparative and international law, the view that the age of the individual should not be considered as a parameter for his working capability is accepted..$^{57}$ This should be proven in every particular case. If we consider the age of the individual as a parameter for his working capability, then we enter a dangerous zone of making prejudices and discrimination. This is exactly what the Constitutional court does.

In the second case, a proceeding was initiated before the Constitutional Court related to assessment of the constitutionality and legitimacy of the provision for awarding scholarships for second-cycle studies in the country for the academic year 2009/2010 as of February 15, 2010, published on the website of the Ministry of Education and Science. The complainant focuses on age as a criterion for receiving this scholarship, which is considered discriminatory and therefore contrary to the constitutional and legal provisions, including Article 9 of the Constitution, as well as the Law on Prevention and Protection from discrimination. 58

The Constitutional Court does not launch an initiative for assessing the constitutionality and legitimacy of the competition, arguing that the Minister of Education and Science has the legal authority to determine the criteria for obtaining a scholarship, performing operationalization of legal norms with such method. Taking into consideration that the Minister acts within his own jurisdictions, there is no violation of the principle of constitutionality and legitimacy. The second argument of the Court is that it is a scholarship provided by the state and given its own economic power, the state alone determines who can apply as a user of such scholarship 59 .

In this case too, the both arguments of the Constitutional Court are not soundly elaborated. The first argument, that the minister has the legal right to prescribe the conditions and criteria for scholarships, is not appropriate, because the Minister in prescribing these criteria must not discriminate on any ground, including age. The Minister has a discretionary right, but it should not be applied arbitrary. The second argument is stronger, that the state provides these scholarships, so therefore they have the right to determine the terms of the scholarship. For this reason, in conditions of unemployment, the state determines to give scholarships to young unemployed persons. ${ }^{60} \mathrm{In}$ other words, this suggests the existence of an objective goal for the criteria-age at obtaining a scholarship, and the goal is easier employment of young unemployed persons. However, the Court does not assess whether this criterion is necessary and appropriate for achieving the goal. Or, whether this criteria goes too far in achieving the goal, thus making unnecessary discrimination. This is explained especially because the following question arose: "Why not provide scholarships for older unemployed persons"? Another question is: "What happens with the process of life-long learning that the state promotes so much?" The Constitutional Court does not analyze these questions, claiming that the state has the right to determine the criteria. But, the Constitutional court somehow forgets that the state also has an obligation to guarantee equality and nondiscrimination.

In this stage of the development of the age-based discrimination concept, the Constitutional court fails to apply the proportionality test in every case. The Court must estimate whether using age as a criterion is really necessary. If there are enough arguments, and researches prove that age is a necessary criterion for achieving a certain legitimate goal (for example, to increase the rate of employment of youth), this claim can subsist. The Constitutional court must consider everything else as discrimination.

\section{Conclusion}

Age discrimination is relatively new legal concept in the Republic of Macedonia. Legislation is adopted with the intention to offer protection against this form of discrimination. With this legislation, the international and EU standards on the matter are well implemented. However, the Law on Prevention and Protection from Discrimination has been adopted in 2010, and is being applied just from 2011. As a new piece of legislation, introducing new legal concept, courts and other institutions dealing with cases on age discrimination, have difficulties to effectively apply it. The courts need to better apply the test of necessity, which will put age distinctions under a judicial review, rather than just accepting them as being

${ }^{56}$ Constitutional Court of the Republic of Macedonia, Decision U. br. 118/2003, Decision of 16.07.2003.

${ }^{57}$ See e.g. Malcolm Sargeant, AGE DISCRIMINATION IN EMPLOYMENT, 2006, page 7.

${ }^{58}$ Constitutional Court of the Republic of Macedonia, U.br. 138/2010, Decision of 10.11.2010.

59 Ibid.

$60 / \mathrm{lbid}$. 
"objective".

On the other hand, even individuals have difficulties to recognize age discrimination. This is shown especially by the very low number of cases reported on age discrimination. The low number of cases shows that there is a need to better promote this concept, to make individuals aware of the fact that age is not an objective criterion to make distinctions, whether in employment, education, social services or other benefits.

\section{References}

International Covenant on Economic, Social and Cultural Rights, 993 U.N.T.S. 3; S. exec. Doc D. 95-2 (1978), Treaty Doc. No. 95-19, 6, I.L.M. 360 (1967);

Ombudsman of the Republic of Macedonia, Annual Report on the level of fulfillment, respect, advancement and protection of human rights and freedoms for 2013, Skopje, March 2014, available at http://ombudsman.mk/MK/godishni_izveshtai.aspx [accessed 01 October 2014];

Ombudsman of the Republic of Macedonia, Annual Report on the level of fulfillment, respect, advancement and protection of human rights and freedoms for 2012, Skopje, March 2013, available at http://ombudsman.mk/MK/godishni_izveshtai.aspx [accessed 01 October 2014];

Ombudsman of the Republic of Macedonia, Annual Report on the level of fulfillment, respect, advancement and protection of human rights and freedoms for 2011, Skopje, March 2012, available at http://ombudsman.mk/MK/godishni_izveshtai.aspx [accessed 01 October 2014];

Commission for protection from discrimination, Regular Annual Report of the Commission for protection against Discrimination, 2011, Skopje, March 2012, available at www.kzd.mk [accessed 21.10.2014];

Commission for protection from discrimination, Regular Annual Report of the Commission for protection against Discrimination, 2012 , Skopje, March 2013, available at www.kzd.mk [accessed 21.10.2014];

Commission for protection from discrimination, Regular Annual Report of the Commission for protection angainst Discrimination, 2013, Skopje, April 2014, available at www.kzd.mk [accessed 21.10.2014]

Zhaneta Poposka, Bekim Kadriu, Lence Koceska, Elena Kocoska, Analysis of the discriminatory practices in the area of employment and labour relations, Skopje, 2013;

Rebecca Zahn, The EU Lisbon Treaty: What Implications for anti racism, Brussels, 2009;

Violeta Petroska Beshka, Mirjana Najcevska, Barometer for equal opportunity, Skopje, 2009;

Peter Hall, Social Capital in Britain, British Journal of Political Science, 29/3, 1999

John Bynner, Improving Adult Basic Skills: Benefits to the Individual and to the Society, Research Report Department for Education and Employment, Nottingham, 2001;

Malcolm Sargeant, Age Discrimination in Employment, Gower Publishing Limited, 2006;

Jasmina Mihailoska, Misha Popoviq, Barometer of equal opportunity, Skopje, 2013;

Marianne Gijzen, Selected Issues in Equal Treatment Law: a Multi-Layered Comparison of European, English and Dutch Law, Intersentia, 2006;

Tom Schuller, Age Equality in Access to Education, вo Age as an equality issue, Legal and policy perspectives, (Sandra Fredman and Sarah Spencer, eds), Oxford and Portland, 2003;

Treaty of Lisbon amending the Treaty on European Union and the Treaty establishing the European Community, 0.J. C 306/01 (13 December, 2007) available at http://eur-lex.europa.eu/JOHtml.do?uri=OJ:C:2007:306:SOM:EN: [accessed 01 10.2014].

European Court of Justice, Case C-411/05, Palacios de la Villa v. Cortefiel Servicios SA, Judgment of 16 October 2006, available at http://eur-lex.europa.eu/LexUriServ/LexUriServ.do?uri=CELEX:62005CJ0411:EN:HTML, [accessed 15.10.2014];

Proposal for a Council Directive on implementing the principle of equal treatment between persons irrespective of religion or belief, disability, age or sexual orientation, SEC(2008) 2180), 2 July 2008, available at http://eur-lex.europa.eu/LexUriServ/LexUriServ. do?uri=CELEX:52008PC0426:EN:NOT [accessed 19.10.2014].

Council Directive 2000/78/EC of 27 November 2000 establishing a general framework for equal treatment in employment and occupation, O.J. L 303, 02/12/2000 P. 0016 - 0022:

Charter of Fundamental Rights of the European Union, 26 October 2012, 2012/C 326/02) available at ex.europa.eu/LexUriServ/Lex UriServ.do?uri=OJ:C:2010:083:0389:0403:en:PDF [accessed on 7 October 2014];

The Constitution of the Republic of Macedonia, Official Gazette of the Republic of Macedonia, No. 52/1991;

The Law on Prevention and Protection from Discrimination, Official Gazette of the Republic of Macedonia, No 50/2010;

Constitutional Court of the Republic of Macedonia, U.br. 118/2003, Decision of 16.07.2003, available at www.ustavensud.mk [last accessed 22.10.2014];

Constitutional Court of the Republic of Macedonia, U.br. 138/2010, Decision of 10.11.2010, available at www.ustavensud.mk [last accessed 22.10.2014]. 